\title{
Induksi Mutasi Fisik pada Paku Bintik (Microsorum punctatum) melalui Iradiasi Sinar Gamma
}

\section{Physically Induced Mutation on Paku Bintik (Microsorum punctatum) by Gamma Irradiation}

\author{
Qisthi Kustia Rahman dan Syarifah lis Aisyah*
}

Departemen Agronomi dan Hortikultura, Fakultas Pertanian, Institut Pertanian Bogor

(Bogor Agricultural University), Jalan Meranti, Kampus IPB Darmaga, Bogor 16680, Indonesia.

Telp. \& Faks. 0251-8629353 e-mail: agronipb@indo.net.id

*Penulis untuk korespondensi : syarifahiis@yahoo.com

\section{Disetujui 20 Agustus 2018 / Published online 3 September 2018}

\begin{abstract}
Mutation breeding by gamma ray is one kind of treatment to increase the genetic diversity of plant. The aims of this research is to know the radiosensitivity and $L D_{50}$ (Lethal dose 50) value on $\underline{M}$. punctatum and plant morphology observes in $\underline{M}$. punctatum resulted by gamma ray irradiation on the MVI. $L D_{50}$ value is one of the parameters for measuring the sensitivity level of plant tissue treated by irradiation. The lower value of $L D_{50}$ of a plant tissue, the higher level of radiosensitivity, which leads to greater chance of mutation occurence. Research was arranged in randomized completely design with single factor (gamma ray doses) with three replications. Gamma ray irradiation given to rhizome cuttings with one leaf from $\underline{M}$. punctatum with acute irradiation using a Gamma Cell 220 with doses of 0, 10, 20, 30, 40, and 50 gray. All of the rhizome with one leaf planted up to weeks after irradiation. The result showed that the treatment of gamma irradiation on $\underline{M}$. punctatum produce $L D_{50}$ is 86,25 gray and the use of gamma ray irradiation on $\underline{M}$. punctatum produced significantly different on plant height and leaves width, but there was no different on leaves number. Irradiation treatment also causes a deficiency of green colour on the leaves of $\underline{M}$. punctatum. Morphologically, the gamma ray irradiation treatment on $\underline{M}$. punctatum has not produced the desired mutants yet, but genetically, there was doubling on chromosome number and chromosome aberration at the highest irradiation dose (50 gray).
\end{abstract}

Keywords: $L D_{50}$, ornamental plant, radiosensitivity.

\begin{abstract}
ABSTRAK
Pemuliaan mutasi dengan iradiasi sinar gamma merupakan salah satu cara dalam meningkatkan keragaman genetik tanaman. Tujuan penelitian ini adalah mengetahui radiosensitivitas dan nilai $\mathrm{LD}_{50}($ Lethal dose 50) sinar gamma pada $M$. punctatum serta mengamati keragaan tanaman $M$. punctatum hasil iradiasi sinar gamma pada MV1. Nilai $\mathrm{LD}_{50}$ merupakan salah satu parameter untuk mengukur tingkat sensitivitas suatu jaringan terhadap iradiasi. Semakin rendah nilai $\mathrm{LD}_{50}$ suatu jaringan tanaman, semakin tinggi tingkat radiosensitivitasnya, sehingga semakin besar peluang terjadinya mutasi. Penelitian ini menggunakan rancangan acak lengkap (RAL) faktor tunggal (dosis iradiasi sinar gamma) dengan 3 ulangan. Iradiasi sinar gamma diberikan terhadap stek rimpang dengan satu daun dari tanaman $M$. punctatum secara tunggal (acute irradiation) menggunakan Gamma Cell 220 dengan dosis 0, 10, 20, 30, 40, dan 50 gray. Semua rimpang dengan satu daun hasil iradiasi ditanam di lapangan hingga 16 minggu setelah iradiasi (MSI). Hasil penelitian menunjukkan bahwa pemberian iradiasi sinar gamma pada $M$. punctatum menghasilkan $\mathrm{LD}_{50}$ sebesar 86,25 gray dan perlakuan iradiasi sinar gamma antar perlakuan berbeda nyata terhadap tinggi dan lebar daun, sedangkan karakter jumlah daun tidak berbeda nyata. Perlakuan iradiasi juga menyebabkan defisiensi warna hijau pada daun M. punctatum. Secara morfologi, perlakuan iradiasi sinar gamma terhadap $M$. punctatum belum menghasilkan mutan-mutan yang diinginkan, namun secara genetik, terdapat penggandaan jumlah kromosom dan aberasi kromosom pada perlakuan dosis iradiasi tertinggi (50 gray).
\end{abstract}

Kata kunci: $\mathrm{LD}_{50}$, radiosensitivitas, tanaman hias. 


\section{PENDAHULUAN}

Subsektor hortikultura merupakan salah satu bagian dari sektor pertanian yang berpotensi untuk dikembangkan. Subsektor ini dapat menjadi salah satu sumber pertumbuhan ekonomi Indonesia. Menurut Kementan (2015) produksi hortikultura pada tahun 2014 mengalami peningkatan sebesar $6,63 \%$ dibandingkan dengan tahun 2013. Peningkatan produksi hortikultura tersebut menyebabkan peningkatan produk domestik bruto (PDB) hortikultura yaitu sebesar Rp 118,2 triliyun pada tahun 2013 menjadi Rp 124,3 triliyun pada tahun 2014 (Kementan, 2016a).

Subsektor hortikultura mencakup buahbuahan, sayuran, tanaman hias dan bunga (florikultura), serta biofarmaka (Poerwanto dan Susila, 2014). Tanaman hias dan bunga (florikultura) merupakan salah satu komponen subsektor hortikultura yang belum dikembangkan secara optimal. Menurut Kementan (2016b), ratarata pertumbuhan produksi florikultura dalam enam tahun terakhir adalah sebesar 10,43\%. Produk florikultura meliputi bunga potong, daun potong, tanaman pot, dan tanaman lanskap. Komoditas florikultura dari kelompok daun potong mengalami laju kenaikan produksi sebesar 19,44\% per tahun (Kementan, 2016a). Tanaman hias daun potong yang berpotensi dikembangkan adalah tanaman paku.

Tanaman paku banyak dimanfaatkan sebagai tanaman hias meskipun tidak mempunyai bunga, tetapi memiliki nilai keindahan dari bentuk daunnya. Keindahan daun dan kotak sporanya telah banyak menarik perhatian pecinta tanaman hias sehingga tanaman ini mulai dimanfaatkan sebagai tanaman hias. Tanaman hias daun jenis paku yang berpotensi untuk dikembangkan adalah paku bintik (Microsorum punctatum). Tanaman ini berpotensi dikembangkan di Indonesia karena permintaan dalam negeri yang tinggi dalam bidang dekorasi dan pembudidayaan yang relatif mudah.

Kendala yang dihadapi petani tanaman paku bintik di lapangan antara lain yaitu sulit mendapatkan keragaan $M$. punctatum yang daunnya bergelombang pada bagian apex (ujung daun), sedangkan yang diminati para dekorator adalah $M$. punctatum yang memiliki keragaan daun yang tebal dan bergelombang pada bagian apex. Hal tersebut menjadi dasar pemikiran penelitian pemuliaan tanaman paku $M$. punctatum ini untuk mendapatkan klon $M$. punctatum dengan kualitas yang lebih baik. Peningkatan keragaman dapat diciptakan melalui program pemuliaan, di antaranya hibridisasi, koleksi, introduksi, dan mutasi induksi (Crowder, 1986).

Peningkatan keragaman tanaman $M$. punctatum dapat dilakukan melalui mutasi induksi fisik dengan iradiasi sinar gamma. Mutasi merupakan perubahan materi genetik sebagai sumber pokok dari semua keragaman genetik dan merupakan bagian dari fenomena alam (Aisyah, 2013). Salah satu mutagen yang digunakan para pemulia untuk dapat menyebabkan mutasi yaitu sinar gamma. Teknik iradiasi yang umum digunakan yaitu acute irradiation atau iradiasi tunggal, yaitu teknik pemberian dosis secara sekaligus dalam satu kali penembakan iradiasi.

Mutasi yang dikehendaki umumnya berada pada kisaran Lethal Dose $50\left(\mathrm{LD}_{50}\right)$ karena pada dosis tersebut menghasilkan variasi maksimal dengan jumlah mutan tidak diinginkan yang minimal (Albokari et al., 2012). $\mathrm{LD}_{50}$ yaitu dosis yang menyebabkan kematian $50 \%$ populasi tanaman yang diradiasi. Melalui mutasi induksi iradiasi sinar gamma pada $M$. punctatum ini diharapkan bisa dapat meningkatkan nilai estetika dan nilai ekonomis tanaman ini sebagai tanaman hias. Tujuan penelitian ini adalah mengetahui radiosensitivitas dan nilai $\mathrm{LD}_{50}$ (Lethal dose 50) sinar gamma pada $M$. punctatum serta mengamati perubahan keragaan tanaman $M$. punctatum hasil iradiasi sinar gamma.

\section{BAHAN DAN METODE}

Penelitian ini dilaksanakan sejak bulan Desember 2016 hingga Agustus 2017. Iradiasi tanaman $M$. punctatum dengan sinar gamma dilakukan di Pusat Aplikasi Isotop dan Radiasi Badan Tenaga Nuklir Nasional (PAIR BATAN) Pasar Jumat, Jakarta. Penanaman hasil iradiasi $M$. punctatum dilakukan di kebun milik PT. Pesona Daun Mas Asri, Ciawi, Bogor. Uji kromosom dilaksanakan di Laboraturium Morfologi, Anatomi, dan Sitologi Tumbuhan, Lembaga Ilmu Pengetahuan Indonesia (LIPI). Bahan yang digunakan adalah tanaman $M$. punctatum bagian rimpang dengan satu daun yang diasumsikan berumur sama dan mendapat budidaya yang sama sebelum perlakuan iradiasi. Rimpang dengan satu daun tanaman diradiasi dengan sinar gamma dengan dosis $0,10,20,30,40$, dan 50 Gray. Bahan lain yang akan digunakan dalam penelitian ini yaitu media tanam (sekam dan kompos dengan perbandingan 2:3), pupuk Urea $\left(100 \mathrm{~kg} \mathrm{ha}^{-1}\right)$ dan TSP (100 kg ha $\left.{ }^{-1}\right)$, fungisida, 8-Hydroxyquinolin, Asam asetat, $\mathrm{HCl} 1 \mathrm{~N}$, dan Aceto orcein 2\%. Alat yang akan digunakan antara lain Gamma Cell 220, paranet $65 \%$ sebagai naungan, polybag, gunting tanaman, label, selang, penggaris, Mini 
Royal Horticulture Society Colour Chart, botol kecil, waterbath, gelas arloji, kaca objek, kaca penutup, cawan petri, pinset, pisau scalpel, pipet tetes, mikroskop, dan peralatan penunjang penelitian lain. Penelitian ini menggunakan Rancangan Acak Lengkap (RAL) dengan satu faktor yaitu dosis iradiasi sinar gamma. Terdapat enam dosis iradiasi yaitu $0,10,20,30,40$, dan 50 Gray dengan 3 ulangan sehingga diperoleh 18 satuan percobaan. Setiap satuan percobaan terdiri atas 4 rimpang dengan satu daun tiap rimpangnya.

Model rancangan yang digunakan (Gomez dan Gomez, 1995) adalah:

Keterangan:

$$
\mathrm{Y}_{\mathrm{ij}} \quad=\mu+\alpha_{\mathrm{i}}+\varepsilon_{\mathrm{ij}}
$$

$\mathrm{i}=$ Perlakuan ke-i $(1,2,3,4,5,6)$

$\mathrm{j} \quad=$ Ulangan ke-j $(1,2,3)$

$\mathrm{Y}_{\mathrm{ij}} \quad=$ Pengamatan pada dosis iradiasi ke-i dan ulangan ke-j

$\mu \quad=$ Rataan umum

$\alpha_{\mathrm{i}} \quad=$ Pengaruh dosis radiasi ke-i

$\varepsilon_{\mathrm{ij}} \quad=$ Pengaruh galat percobaan pada dosis iradiasi ke-i, ulangan ke-j

Bahan tanaman untuk percobaan berupa rimpang dengan satu daun. Rimpang dengan satu daun tersebut dikemas dalam wadah dari kertas. Tiap wadah tersebut berisi 4 rimpang dengan 1 daun pada masing-masing rimpang, diberi label perlakuan enam dosis iradiasi yang berbeda, sehingga terdapat 24 kemasan yang kemudian dibawa ke PAIR BATAN, Pasar Jumat, Jakarta untuk diradiasi. Tanaman yang tidak mendapat perlakuan iradiasi (0 Gray) juga ikut dibawa ke BATAN. Transportasi bukan merupakan perlakuan sehingga seluruh tanaman harus menerima kondisi yang sama.

Bahan tanaman dalam wadah disiapkan untuk proses iradiasi. Iradiasi sinar gamma dilakukan menggunakan Gamma Cell 220. Aplikasi dilakukan sebanyak satu kali (acute irradiation) dengan lima taraf dosis iradiasi. Ketiga wadah berlabel dosis iradiasi dimasukkan ke dalam Gamma Cell 220 secara bersamaan sesuai dosis yang diberikan secara bergantian. Waktu yang dibutuhkan selama proses iradiasi tergantung dosis iradiasi yang diberikan.

Tanaman yang telah diradiasi dan tanaman kontrol selanjutnya ditanam dalam polybag. Media tanam disiapkan untuk penanaman. Rimpang dengan satu daun ditanam, satu rimpang dengan satu daun per-polybag. Polybag diisi dengan campuran media tanam, selanjutnya rimpang besertta satu daun $M$. punctatum dipindah dengan hati-hati. Selama masa pertanaman, polybag tanaman disimpan di PT. Pesona Daun Mas Asri, Ciawi, Bogor dengan menggunakan naungan paranet $55 \%$ yang bertujuan untuk melindungi tanaman dari hujan dan panas yang berlebihan. Pemeliharaan tanaman dengan penyiraman dilakukan dua hari sekali pada pagi hari. Pupuk TSP dan Urea diberikan pada 1 dan 9 MSI dengan dosis $100 \mathrm{~kg} \mathrm{ha}^{-1}$.

Satu tanaman dari setiap dosis diambil dari polybag untuk menguji kromosom dari bagian akar. Bagian akar dicuci bersih. Akar muda muda dipotong sekitar 0,5-1 cm, akar tersebut direndam dalam larutan 8Hydroxyquinolin 0,002 $\mathrm{M}$, dimasukkan dalam lemari pendingin $\left( \pm 4^{\circ} \mathrm{C}\right)$ selama $3-5$ jam, selanjutnya akar dikeluarkan dari larutan Hydroxyquinolin, dicuci dengan air, dan direndam dalam larutan asam asetat $45 \%$ selama 10 menit. Setelah itu, akar dimasukkan ke dalam larutan $\mathrm{HCl} 1 \mathrm{~N}$ dan asam asetat $45 \%$ dengan perbandingan (3:1) dalam sebuah botol kecil yang memiliki penyangga untuk dipanaskan di waterbath dengan suhu konstan $60^{\circ} \mathrm{C}$ selama 3-5 menit lalu akar dikeluarkan dari larutan $\mathrm{HCl}$ dan Asam asetat. Selanjutnya, akar ditaruh di plat tetes untuk ditetesi Aceto orcein 2\% dan dibiarkan selama 10-30 menit untuk tanaman yang diberi perlakuan dan 24 jam untuk tanaman kontrol. Akar diletakkan pada kaca objek, bagian ujung akar dipotong 1-2 mm, ditetesi dua tetes Aceto orcein $2 \%$ dan ditutup dengan kaca penutup. Kemudian preparat diketuk dengan menggunakan pensil berkaret (squash), lalu ditekan dengan ibu jari, dan preparat diamati di bawah mikroskop untuk melihat kromosom dalam sel tanaman.

Pengamatan dilakukan mulai dua minggu setelah iradiasi (MSI) pada seluruh tanaman. Pengamatan terdiri atas pengamatan morfologi dan pengamatan genetik. Pengamatan morfologi terdiri atas pengamatan kuantitatif dan kualitatif. Pengamatan kuantitatif terdiri atas persentase tanaman hidup tiap dosis iradiasi (\%), tinggi tanaman $(\mathrm{mm})$, dan lebar daun terlebar $(\mathrm{mm})$. Karakter kualitatif yang diamati terdiri atas warna daun menggunakan Mini Royal Horiculture Society Colour Chart (Mini RHSCC) dan keragaan morfologi khusus pada mutan putatif yang dihasilkan setelah iradiasi. Pengamatan genetik menghitung jumlah kromosom (buah) yang nampak pada sebuah sel dengan bantuan mikroskop dengan perbesaran 1.000 kali.

Penentuan dosis $\mathrm{LD}_{50}$ menggunakan perangkat lunak Curve Fit Expert Analysis yang mengacu pada penelitian yang dilakukan oleh Marthin (2014). Nilai $\mathrm{LD}_{50}$ ditentukan berdasarkan persentasi tanaman hidup pada tiap taraf dosis iradiasi. Data hasil pengamatan yang diperoleh dianalisis untuk mengetahui pengaruh 
dari perlakuan dengan menggunakan uji t-student pada taraf $\alpha=5 \%$.

\section{HASIL DAN PEMBAHASAN}

\section{Kondisi Umum}

Selama proses penelitian berlangsung, organisme pengganggu yang menyerang tanaman M. punctatum adalah jamur Fusarium sp. Menurut Herlina (2009), budidaya komoditas pertanian tidak lepas dari serangan patogen antara lain jamur Fusarium sp. khususnya $F$. oxysporum yang menyebabkan penyakit layu daun. Serangan Fusarium sp. pada saat penelitian dapat dikatakan cukup tinggi sehingga mengakibatkan banyak tanaman layu hingga mati. Serangan penyakit ini banyak terjadi pada tanaman dengan aplikasi dosis iradiasi sinar gamma 50 Gray (dosis aplikasi tertinggi yang digunakan). Hal ini menunjukkan bahwa tanaman yang mendapat aplikasi dosis tersebut menjadi rentan terserang penyakit. Kondisi tersebut juga terjadi pada efek iradiasi sinar gamma pada dosis tinggi menyebabkan tanaman Aglaonema sp. rentan terhadap Fusarium sp. (Misniar, 2008). Cara penanggulangan yang dilakukan adalah dengan memisahkan tanaman terserang agar tidak menular ke tanaman lainnya.

\section{Nilai Lethal Dose 50 (LD50)}

Kisaran dosis dalam pengaplikasian iradiasi bahan tanam sangat penting untuk mendapatkan dosis optimum iradiasi suatu bahan tanam (Boertjes dan van Harten, 1988). Dosis optimum dapat menghasilkan variasi terbanyak dengan minimal mutan yang tidak diinginkan, yang biasa terjadi di sekitar $\mathrm{LD}_{50}$ (Albokari et al., 2012). Lethal Dose $50\left(\mathrm{LD}_{50}\right)$ adalah dosis yang menyebabkan kematian $50 \%$ populasi tanaman (Asadi, 2011). Namun belum ditemukan literatur yang mendukung untuk penggunaan dosis optimum iradiasi sinar gamma pada tanaman $M$. punctatum sehingga digunakan aplikasi dosis 1050 Gray. Nilai $\mathrm{LD}_{50}$ didapat dari perhitungan persentase tanaman yang hidup setelah iradiasi dengan menggunakan aplikasi Curve Fit Expert Analysis. Model dengan koefisien korelasi $(r)$ tertinggi yang digunakan untuk menentukan nilai $\mathrm{LD}_{50}$.

Tabel 1. Persentase tanaman yang mati pada 5 minggu setelah iradiasi (MSI)

\begin{tabular}{cc}
\hline Perlakuan iradiasi (Gray) & Tanaman mati (\%) \\
\hline 0 & 0,00 \\
10 & 0,00 \\
20 & 0,00 \\
30 & 22,22 \\
40 & 11,11 \\
50 & 33,33 \\
\hline
\end{tabular}

Persentase tanaman $M$. punctatum mati yang diamati mulai 1 MSI (Minggu Setelah Iradiasi) hingga 5 MSI berbeda tiap perlakuan dosis iradiasi. Tanaman M. punctatum pada dosis
0 Gray hingga 50 Gray cenderung mengalami peningkatan persentase kematian seiring bertambahnya dosis iradiasi (Tabel 1).

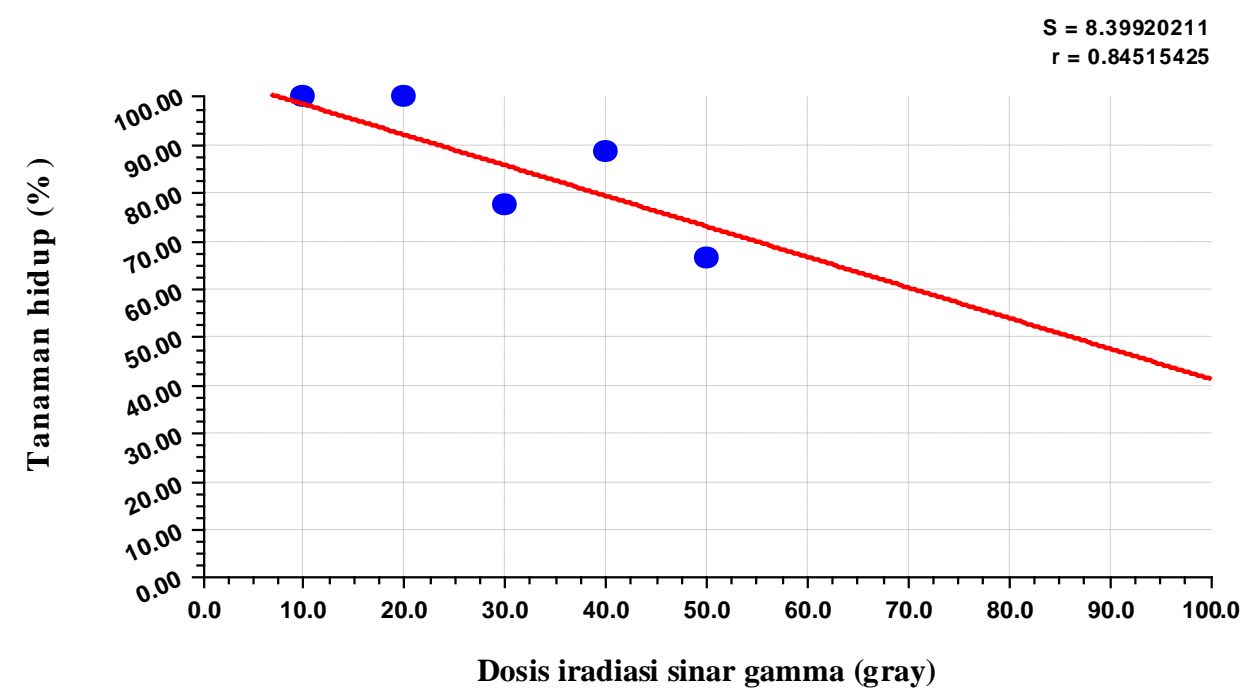

Gambar 1. Kurva persentase tanaman hidup pada M. punctatum setelah iradiasi. 
Pola sebaran persentase tanaman hidup pada $M$. punctatum dideskripsikan dengan fungsi Linear Fit yang merupakan fungsi terbaik pada Curve Fit Expert Analysis dengan nilai korelasi model $\mathrm{r}=0,85$, nilai probabilitas dari regresi tersebut sebesar 0,034 , dan memiliki persamaan y $=104,76-0,63 \times$ (Gambar 1). Nilai $\mathrm{LD}_{50}$ yang diperoleh dari hasil persamaan tersebut sebesar 86,25 Gray. Hal ini menunjukkan bahwa pada dosis 86,25 gray dapat menyebabkan kematian $50 \%$ dari populasi M. punctatum.

Nilai $\mathrm{LD}_{50}$ merupakan salah satu parameter untuk mengukur tingkat sensitivitas suatu jaringan terhadap iradiasi, atau lebih dikenal dengan istilah 'radiosensitivitas' (Aisyah, 2006). Nilai $\mathrm{LD}_{50}$ berbanding terbalik dengan tingkat radiosensitivitas. Menurut Herison (2008), semakin rendah $\mathrm{LD}_{50}$ suatu tanaman, maka semakin tinggi tingkat radiosensitivitasnya. Soedjono (2003) mengelompokkan dosis iradiasi menjadi tiga kategori, yaitu tinggi (>10 kilogray), sedang (1-10 kilogray), dan rendah ( $<1$ kilogray). Berdasarkan pengelompokkan tersebut, nilai $\mathrm{LD}_{50}$ tanaman M. punctatum termasuk kategori rendah, maka radiosensitivitas tanaman tersebut tinggi. Aisyah (2006) menyatakan bahwa setiap spesies tanaman atau klon dalam suatu spesies tanaman mempunyai tingkat sensitivitas terhadap radiasi yang berbeda-beda. Conger et al. (1977) mengemukakan bahwa respon sel tanaman terhadap mutagen fisik dipengaruhi oleh faktor lingkungan dan faktor biologis. Faktor lingkungan tersebut yaitu oksigen, kadungan air, penyimpanan pascaradiasi, dan suhu. Adapun faktor biologis terdiri atas genetik/perbedaan varietas dan volume inti sel.

\section{Karakter Kuantitatif}

Pada penelitian ini hanya dilakukan pengamatan terhadap karakter vegetatif saja, sedangkan karakter generatif tidak diamati. Hal ini disebabkan oleh lambatnya pertumbuhan tanaman M. punctatum selama 16 MSI penelitian ini dilakukan, tidak ada pertumbuhan tanaman yang berarti secara signifikan. Karakter vegetatif yang diamati meliputi tinggi tanaman $(\mathrm{mm})$, lebar daun terlebar $(\mathrm{mm})$, dan jumlah daun (helai).

Tabel 2. Rataan tinggi, rataan lebar daun, dan rataan jumlah daun tanaman M. punctatum

\begin{tabular}{ccccccc}
\hline \multirow{2}{*}{$\begin{array}{c}\text { Dosis iradiasi } \\
\text { (Gray) }\end{array}$} & \multicolumn{2}{c}{ Tinggi tanaman $(\mathrm{mm})$} & \multicolumn{2}{c}{ Lebar daun $(\mathrm{mm})$} & \multicolumn{2}{c}{ Jumlah daun (helai) } \\
\cline { 2 - 7 } & Rata-rata & Kisaran & Rata-rata & Kisaran & Rata-rata & Kisaran \\
\hline 0 & $142,26 \mathrm{a}$ & $115-175$ & $21,69 \mathrm{ab}$ & $13-29$ & 1,17 & $1-3$ \\
10 & $135,88 \mathrm{ab}$ & $110-171$ & $19,61 \mathrm{~b}$ & $11-27$ & 1,00 & 1 \\
20 & $130,80 \mathrm{ab}$ & $108-160$ & $23,50 \mathrm{a}$ & $20-28$ & 1,00 & 1 \\
30 & $126,09 \mathrm{~b}$ & $90-179$ & $18,86 \mathrm{~b}$ & $11-24$ & 1,00 & 1 \\
40 & $122,83 \mathrm{ab}$ & $0-171$ & $20,99 \mathrm{ab}$ & $0-28$ & 1,00 & 1 \\
50 & $134,56 \mathrm{ab}$ & $114-178$ & $23,32 \mathrm{a}$ & $12-28$ & 1,00 & 1 \\
\hline
\end{tabular}

Secara umum, dibuktikan dengan analisis uji $\mathrm{F}$, perlakuan dosis iradiasi sinar gamma tidak berpengaruh terhadap karakter tinggi tanaman $(\mathrm{mm})$, lebar daun terlebar ( $\mathrm{mm})$, dan jumlah daun (helai) sehingga digunakan uji t-student untuk melihat perbedaan antar perlakuan.

Rataan tinggi tanaman cenderung menurun dari perlakuan 0 Gray hingga 40 Gray, dan pada perlakuan 50 Gray cenderung meningkat (Tabel 2). Rataan tinggi tanaman tertinggi berada pada perlakuan kontrol (0 Gray), sedangkan rataan tinggi tanaman terendah berada pada perlakuan dengan dosis iradiasi 40 Gray. Berbeda dengan data rataan tinggi tanaman, rataan lebar daun terlebar cenderung berfluktuasi dari perlakuan kontrol (0 Gray) hingga perlakuan 50 Gray. Hal ini disebabkan oleh bentuk daun dari tanaman $M$. punctatum yang beragam ukuran daunnya. Berdasarkan Tabel 2, karakter jumlah daun tanaman $M$. punctatum relatif sama atau tidak berbeda nyata. Tanaman kontrol berpotensi memiliki jumlah daun sebanyak 3 helai dibandingkan dengan tanaman yang diberi perlakuan iradiasi.

Hasil uji t-student pada tabel 2 menunjukkan bahwa karakter tinggi tanaman $M$. punctatum tidak berbeda antarperlakuan, kecuali antara perlakuan 0 Gray dengan perlakuan 30 Gray. Hal ini menunjukkan bahwa tanaman $M$. punctatum menunjukkan respon yang berbeda terhadap perlakuan dosis iradiasi. Fenomena pertumbuhan yang tidak merata sering terjadi pada kasus mutasi. Respon tanaman menjadi lebih bervariasi akibat radiasi pengion yang bekerja secara acak (Aisyah, 2013).

Pengamatan lebar daun terlebar hingga 16 MSI menunjukkan bahwa terdapat perbedaan nyata lebar daun $M$. punctatum antara perlakuan dosis iradiasi. Pelakuan 10 Gray dengan perlakuan 20 Gray berbeda nyata dengan nilai probabilitas 0,01 ; perlakuan 10 Gray dengan perlakuan 50 Gray berbeda nyata dengan nilai probabilitas 0,03 ; dan perlakuan 30 Gray dengan perlakuan 50 Gray berbeda nyata dengan nilai probabilitas sebesar 
0,01, sedangkan perlakuan 20 Gray dengan perlakuan 30 Gray berbeda sangat nyata dengan nilai probabilitas sebesar $<0,01$. Hal tersebut menunjukkan bahwa terdapat pengaruh dosis perlakuan iradiasi sinar gamma terhadap karakter lebar daun tanaman.

Berdasarkan hasil uji t-student, karakter jumlah daun tidak berbeda nyata pada seluruh perbandingan antar perlakuan. Hal tersebut disebabkan oleh perlakuan iradiasi sinar gamma yang menghambat pertumbuhan tanaman $M$. punctatum. Iradiasi dengan sinar gamma juga mengakibatkan penghambatan pertumbuhan pada tanaman temulawak (Mikrom, 2016), Coleus blumei (Togarotop et al., 2016), dan kunyit (Anshori et al., 2014).

\section{Karakter Kualitatif}

Selain karakter kuantitatif, pengamatan terhadap karakter kualitatif juga dilakukan, antara lain terhadap morfologi vegetatif tanaman yang meliputi warna daun. Keunikan karakter yang diamati ini menjadi indikator tanaman mutan pada penelitian ini.

Tabel 3. Warna daun tanaman M. punctatum pada 8 MSI

\begin{tabular}{ccccc}
\hline \multirow{2}{*}{ Dosis iradiasi (Gray) } & \multicolumn{3}{c}{ Warna daun $(\%)$} \\
\cline { 2 - 5 } & Dark green & Green & Light green & Yellow green \\
\hline 0 & 80,00 & 20,00 & 0,00 & 0,00 \\
10 & 44,44 & 33,33 & 0,00 & 22,22 \\
20 & 90,91 & 0,00 & 9,09 & 0,00 \\
30 & 60,00 & 40,00 & 0,00 & 0,00 \\
40 & 62,50 & 25,00 & 0,00 & 12,50 \\
50 & 66,67 & 16,67 & 0,00 & 16,67 \\
\hline
\end{tabular}

Hasil pengukuran warna daun pada tanaman $M$. punctatum menunjukkan bahwa perlakuan iradiasi sinar gamma memberikan pengaruh perubahan warna pada daun $M$. punctatum (Tabel 3). Warna daun pada beberapa tanaman $M$. punctatum yang diberi perlakuan iradiasi sinar gamma berwarna hijau kekuningan dan hijau terang mendekati albino. Hal tersebut dapat disebabkan oleh kerusakan DNA kloroplas ( $c p$ DNA) yang mengakibatkan plastida pada sebagian jaringan kurang atau tidak bisa memproduksi klorofil sehingga terjadi defisiensi warna hijau pada daun (Anshori et al., 2014).

Secara keseluruhan dapat diuraikan bahwa pada penelitian ini belum terbentuk tanaman mutan yang diharapkan. Secara fenotipe belum terlihat perbedaan bentuk tanaman $M$. punctatum, khususnya pada bagian daun. Hal ini disebabkan oleh teknik iradiasi yang digunakan adalah teknik iradiasi tunggal (acute irradiation). Berdasarkan hasil penelitian Indriatama (2016), teknik iradiasi terbagi dan berulang menghasilkan ragam yang lebih besar dibanding iradiasi tunggal pada tanaman gandum (Triticum aestivum L.). Selain itu, perubahan yang terjadi pada MV1 belum terbukti secara genetik dapat diturunkan.

\section{Uji Kromosom}

Menurut Crowder (1986), individuindividu dalam satu spesies biasanya mempunyai jumlah kromosom sama tetapi spesies yang berbeda dalam satu genus sering memiliki jumlah kromosom berbeda. Spesies paku yang berada dalam satu genus yang sama dengan $M$. punctatum memiliki jumlah kromosom yang berbeda. Misalnya pada M. scolopendria memiliki jumlah kromosom 36 buah, sedangkan $M$. lucidium (Roxb.) Copel s. 1. dan M. pteropus yang memiliki jumlah kromosom 72 buah (Goldblatt, 1981).

M. punctatum memiliki tingkat ploidi yang tinggi, yaitu $2 \mathrm{n}=4 \mathrm{x}=72$ (Nakato dan Kato, 2001) dan $2 \mathrm{n}=8 \mathrm{x}=144$ (Love et al., 1977). Hasil uji kromosom pada tanaman M. punctatum perlakuan iradiasi 50 gray memiliki jumlah kromosom $2 n=3 x=54 \quad$ (Gambar 3b), sedangkan jumlah kromosom pada tanaman $M$. punctatum kontrol $2 \mathrm{n}=2 \mathrm{x}=36$ (Gambar $3 \mathrm{a})$, sehingga $\mathrm{x}=18$ pada $M$. punctatum. Hal tersebut menunjukkan bahwa iradiasi sinar gamma mengakibatkan penggandaan jumlah kromosom. Menurut Poespodarsono (1988) mutasi dapat menyebabkan perubahan benang kromosom yang dapat merubah susunan atau letak beberapa gen. Perubahan tersebut dapat berupa penggandaan kromosom. Iradiasi sinar gamma juga menyebabkan perubahan jumlah kromosom pada polen kelapa genjah varietas Salak (Sofiani, 2011). 


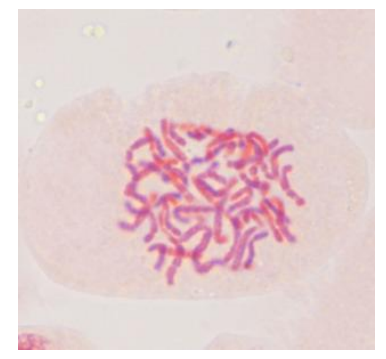

a

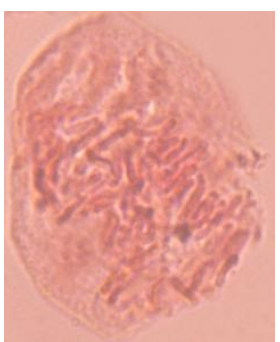

b

(a) Kromosom pada tanaman kontrol

(b) Kromosom pada tanaman diberi perlakuan iradiasi sinar gamma 50 Gray

Gambar 2. Kromosom tanaman M. punctatum pada kontrol dan setelah diberi perlakuan iradiasi 50 Gray

Hasil uji kromosom pada tanaman $M$. punctatum perlakuan iradiasi 50 Gray memiliki jumlah kromosom sebanyak 54 buah (Gambar 2b), sedangkan jumlah kromosom pada tanaman M. punctatum kontrol sebanyak 36 buah (Gambar 2a). Hal tersebut menunjukkan bahwa iradiasi sinar gamma mengakibatkan penggandaan jumlah kromosom. Menurut Poespodarsono (1988), mutasi dapat menyebabkan perubahan benang kromosom yang dapat merubah susunan atau letak beberapa gen. Perubahan tersebut dapat berupa penggandaan kromosom.

Selain jumlah kromosom yang berbeda dengan kontrol, terjadi aberasi kromosom pada tanaman $M$. punctatum yang telah diberi perlakuan iradiasi sinar gamma (gambar 3b). Menurut Lestari (2014) penggunaan mutagen fisik dapat menyebabkan pecahnya benang kromosom (chromosome aberration). Hal tersebut disebabkan oleh penggunaan teknik iradiasi yang digunakan pada penelitian ini adalah tenik iradiasi tunggal (acute irradiation). Teknik radiasi tunggal yaitu teknik pemberian dosis secara sekaligus dalam satu kali penembakan iradiasi (Aisyah, 2013). Penggunaan teknik iradiasi tunggal ini menghasilkan aberasi kromosom bahkan dapat menyebabkan kematian tanaman lebih besar daripada menggunakan teknik iradiasi berulang. Menurut Aisyah (2013) penggunaan teknik iradiasi tunggal memberikan efek iradiasi lebih rendah daripada teknik iradiasi berulang yang diberikan setengah dosis dalam dua kali ulangan.

\section{KESIMPULAN}

Mutasi induksi fisik dengan iradiasi sinar gamma melalui teknik iradiasi tunggal (acute irradiation) pada taraf dosis 10-50 Gray yang diaplikasikan pada stek rimpang dengan satu buah daun $M$. punctatum menghasilkan nilai $\mathrm{LD}_{50}$ sebesar 86,25 Gray. Persentase tanaman mati dari bahan tanaman setelah perlakuan iradiasi menunjukkan peningkatan dari 1 sampai 5 minggu setelah iradiasi (MSI).
Perlakuan iradiasi sinar gamma antar perlakuan berbeda nyata terhadap tinggi dan lebar daun, sedangkan karakter jumlah daun tidak berbeda nyata. Perlakuan iradiasi juga menyebabkan defisiensi warna hijau pada daun $M$. punctatum. Secara morfologi, belum terbentuknya mutan-mutan yang diinginkan, namun secara genetik terdapat penggandaan jumlah kromosom dan kerusakan kromosom pada perlakuan dosis iradiasi tertinggi (50 Gray).

\section{DAFTAR PUSTAKA}

Aisyah. 2013. Mutasi induksi. Dalam:Syukur M. dan Sastrosumarjo S., (eds). Sitogenetika Tanaman. IPB Press, Bogor.

Albokari, M.M.A., S.M. Alzahrani, A.S. Alsalman 2012. Radiosensitivity of some cultivars of wheat (Triticum aestivum L.) to gamma irradiation. Bangladesh J. Bot. 41(1):1-5.

Anshori S.R., S.I. Aisyah, L.K. Darusman. 2014. Induksi mutasi fisik dengan iradiasi sinar gamma pada kunyit (Curcuma domesica Val.). J. Hort. Indonesia 5(3): 84-94.

Asadi. 2011. Pemanfaatan sinar radiasi dalam pemuliaan tanaman. Warta Penelitian dan Pengembangan Pertanian 33(1):7-8.

Boertjes, C., A.M. van Harten. 1988. Mutation Breeding for Vegetatively Propagated Crops. Elsevier Science Publisher, New York.

Conger, B.V., C.F. Konzak, R.A Nilai. 1997. Radiation sensitivity and modifying factors. Dalam: Welsh C.N. $(E d)$. Manual on Mutation Breeding. International Atomic Energy Agency, Vienna. 
Crowder, L.V. 1986. Genetilka Tumbuhan. Alih bahasa: Kusdiarti L. Gadjah Mada University Press, Yogyakarta.

Goldblatt. 1981. Index to Plant Chromosome Number 1975-1978. Braun-Brumfield, Inc., Michigan.

Gomez, K.A., A.A. Gomez. 1995. Prosedur Statistik untuk Penelitian Pertanian. Alih bahasa: Sjamsuddin E. dan Baharsjah J.S. UI Press, Jakarta.

Herison, C., Rustikawati, S.H. Sutjahjo, S.I. Aisyah. 2008. Induksi mutasi iradisi sinar gamma terhadap benih untuk meningkatkan keragaman populasi dasar jagung (Zea mays L.). J. Akta Agrosia 11(1): 57-62.

Herlina, L. 2009. Potensi Trichoderma harzianum sebagai biofungisida pada tanaman tomat. Jurnal Biosaintifika 1(1):62-69.

Indriatama, W.M. 2016. Keragaman genetik gandum (Triticum aestivum L.) hasil perlakuan tiga teknik iradiasi sinar gamma. Tesis. Institut Pertanian Bogor, IPB.

[Kementan] Kementerian Pertanian. 2015. Statistik Produksi Hortikultura 2014. [Internet] [diunduh 2016 September 19] tersedia pada http://hortikultura.pertanian.go.id/?p=153 2

2016a. Revisi Rencana Strategis Direktorat Jenderal Hortikultura Kementerian Pertanian 2015-2019. [Internet] [diunduh 2017 Agustus 10] tersedia pada http://sakip.pertanian.go.id/admin/file/PRI NT\%20Renstra\%20Horti\%20Rev\%20\%2 02015-2019.pdf

. 2016b. Laporan Tahunan Kementerian Pertanian Tahun 2016. [Internet] [diunduh 2017 Agustus 6] tersedia pada http://sakip.pertanian.go.id/admin/tahunan /Laporan\%20Tahunan\%20Kementan\%20 2016.pdf

Lestari, E.G. 2014. Teknik mutasi untuk pemuliaan tanaman. [Internet] [diunduh
2017 September 15] tersedia pada http://biogen.litbang.pertanian.go.id/wp/w p-content/uploads/kalinspdf/singles/tekni k-mutasi-untuk-pemuliaan-tanaman.pdf

Love, A., D. Love, R.E.G. Pichi-Sermolli. 1977. Cytotaxonomical Atlas of the Pteridophyta. J. Cramer, Vaduz.

Marthin, Y. 2014. Peningkatan keragaan Coleus (Coleus sp.) melalui induksi mutasi fisik dengan radiasi sinar gamma. Skripsi. Institut Pertanian Bogor. Bogor.

Mikrom, N.A. 2016. Induksi mutasi fisik pada temulawak (Curcuma xanthorriza Roxb.) dengan Iradiasi Sinar Gamma. Skripsi. Institut Pertanian Bogor. Bogor.

Misniar, R.P. 2008. Pengaruh iradiasi sinar gamma terhadap keragaan tanaman Aglaonema sp. Skripsi. Institut Pertanian Bogor, Bogor.

Nakato, N., M. Kato. 2001. Chromosome numbers of ten species of fern from Guam, S. Mariana Isls. Acta Phytotax, Geobot. 52(2): 125-133.

Poerwanto, R., A.D. Susila. 2014. Teknologi Hortikultura. IPB Press, Bogor.

Poespasdarsono, S. 1988. Dasar-dasar Ilmu Pemuliaan Tanaman. PAU IPB, Bogor.

Soedjono, S. 2003. Aplikasi mutasi induksi dan variasi somaklonal dalam pemuliaan tanaman. Jurnal Litbang Pertanian 22(2):70-78.

Sofiani, L. 2011. Pengaruh iradiasi sinar gamma pada polen kelapa genjah Salak. Skripsi. Institut Pertanian Bogor. Bogor.

Togarotop, E.R., S.I. Aisyah, R.M. Damanik. 2016. Pengaruh mutasi fisik iradiasi sinar gamma terhadap keragaan genetik dan penampilan Coleus blumei. J. Hort. Indonesia 7(3): 187-194.

Wanma, A.O. 2016. Keanekaragaman jenis tumbuhan paku (Pteridophyta) di Gunung Arfak Papua Barat. Tesis. Institut Pertanian Bogor. Bogor. 